\title{
Body Fat Measurement
}

National Cancer Institute

\section{Source}

National Cancer Institute. Body Fat Measurement. NCI Thesaurus. Code C122232.

A measurement of the total fat mass within the subject's body. 